\title{
THE ROLE OF MODULAR CONSTRUCTION IN THE REVIVAL OF TRADITIONAL EMIRATI SOUKS
}

\author{
SARAH KHALIL ELMASRY \\ Interior Architecture Program, College of Fine Arts and Design, University of Sharjah, United Arab Emirates
}

\begin{abstract}
In the Arabian Gulf city of Dubai, high demand in the building industry has led construction companies to rely on modular building components for their proven savings in time and cost. Although the architecture of the retail environment in the city during the previous decades was globalized, lacked identity, and relied on the concept of "Spectacle", an emerging State goal is preserving local heritage and identity, which directly reflected on the architecture of some recently built retail and multi-use developments in Dubai using modular systems. In search of the architectural language prevailing with this movement, the author is seeking to answer the question if modular construction necessarily pulls architecture away from its deeply-rooted identity? Can designers use the characteristics and opportunities which modular construction has to offer while maintaining the original qualities of the local built environment? Through prolonged field observations, it is found that modular construction in this particular Dubai experience was able to re-introduce significant architectural elements of the traditional Emirati souk from the pre-oil era. However, this revival reflected lessons learnt from the nearer past, for example, experimenting with new materials instead of local, natural ones as influenced by experiences from the 1960 s, passive cooling strategies were not taken into consideration, instead, interiors relied on mechanical cooling systems and emphasized the "spectacular" qualities as influenced from the architecture of the 1990s. The Dubai experience during the last decade was able to stretch the limitations of modular construction, from practical to aesthetical, and from "just another" construction method to a contributor the cultural statement. It also successfully initiated a new definition of spectacle, based on cultural, social and sometimes political statements, declined the over-scaled, globalized typologies, and offered a revival of the local Emirati souk for the 21st century.
\end{abstract}

Keywords: architecture, Dubai, local identity, modular construction, retail environments, spectacle, traditional architecture.

\section{INTRODUCTION}

Dubai has been a trading hub since the ruler exempted foreign traders from taxes in 1894 [1]. The city, which is now one of the fastest growing metropolitan areas worldwide according to a January 2015 report from the Brookings Institute [2], had humble beginnings as a fishing village, where pearling constituted the main lifeline. However, its society reflected its outwards-going orientation, as a mercantile, tolerant society.

After the decline of the pearl trade, the city started its transformation into one of sheersize and over-scaled shopping malls and commercial events. In 1981 Dubai opened its first modern shopping mall, which was a breakthrough project for the time [1]. Since then, malls have replaced the traditional Emirati souk as the community knew it. These developments were characterized by their over-scaled, themed western typologies, especially during the 1980s and 1990s, including the typical anchor stores, inwards orientation, and presence of food courts, and adopting the concept of "Spectacle" in their size, layout and architectural features [3].

Recently, what I would call a rebound in the design of Dubai's retail environments has successfully emerged. This movement abandoned the globalized typologies described above, and lent itself to the elements of local traditional architecture, learning from experiences of the past. These projects adopted modular construction approaches, which not only secured 
speedy construction and hand-over time, but also introduced a revolutionary architectural language to the retail environment.

In the coming sections of this paper, I would like to link this trend to the relatively-short architectural history of Dubai since the pre-oil era until today, and investigate how modular construction contributed to this transformation.

\section{ARCHITECTURE IN DUBAI: THE JOURNEY AND THE EVOLUTION}

The architectural journey in Dubai has undergone a number of phases of evolution, which started before discovering oil in the 60s until today. This journey is best described by Velegrinis and Katodrytis [4] in four acts; the pre-modern era (before 1960s), the modernist aspirations (1960s-1990s), aspirations of Hedonistic modernism (1990s-2008), and what they call the "Boom, Bust and Boom" (since 2008), or what I would call the era of architectural self-discovery.

\subsection{The pre-modern era: architecture of the traditional walkable souks}

Before the 1960s, the traditional community inhibiting the area was based on tribal governance and constituted of both nomadic and settled communities who developed their local climate-driven architecture.

As walkability was an essential mean of transport in the extreme weather of Dubai, shading was not a compromise. An essential solution was increasing the density of the urban fabric (Fig. 1). Narrow alleys (sikkas) defining shopping streets provided day-long shading, and increased wind velocity, permitting the north wind to further lower temperatures. Buildings usually were shaped in compact volumes with significant projections in respect to this pattern [5].

Environmental regulators creatively integrated and defined forms along the souk experience. Wind towers (Barajeel); the vertical elements not only gave grace to the building but also confirmed the skyline of the city. Functionally, they acted as conduits for the trapped air to be directed to the rooms beneath. During winter these wind towers were closed with wooden planks. For climate as well as privacy reasons, builders avoided opening windows to the exterior. Windows were replaced with two thin parallel walls with a distance of about $10 \mathrm{~cm}$. in between (air-pullers) which cooled interior spaces (Fig. 2).

Construction materials were locally available ones. Typically roofs and shading elements were covered with palm-tree trunks and fronds, walls were built with mountain stones and mud, while gypsum panels and gypsum powder was used for floral and geometric ornamentation [5].

Environmental regulators creatively integrated and defined forms along the souk experience. Wind towers (Barajeel); the vertical elements not only gave grace to the building

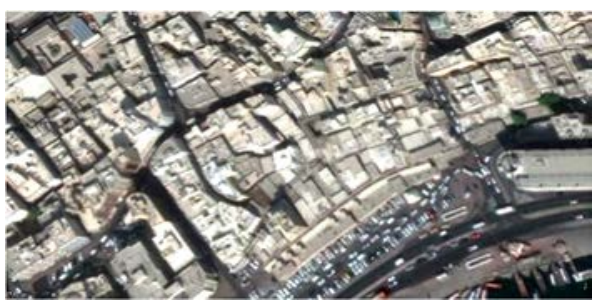

(a)

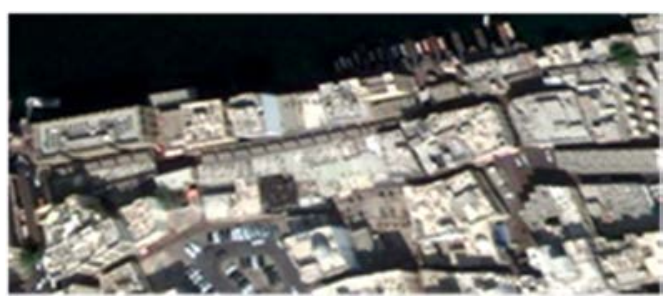

(b)

Figure 1: The dense urban fabric of Dubai old souks. (a) Spice souk; (b) Textile souk. 
but also confirmed the skyline of the city. Functionally, they acted as conduits for the trapped air to be directed to the rooms beneath. During winter these wind towers were closed with wooden planks. For climate as well as privacy reasons, builders avoided opening windows to the exterior. Windows were replaced with two thin parallel walls with a distance of about $10 \mathrm{~cm}$. in between (air-pullers) which cooled interior spaces (Fig. 2).

Construction materials were locally available ones. Typically roofs and shading elements were covered with palm-tree trunks and fronds, walls were built with mountain stones and mud, while gypsum panels and gypsum powder was used for floral and geometric ornamentation [5].

Shading devices covered main walkways. They successfully performed in multiple ways. They were used as form givers to the space, filtering light into the space. Gaps between the building ending and shading surface allowed heated air to escape, and they also were used to define entrances (Fig. 3).

Shading devices covered main walkways. They successfully performed in multiple ways. They were used as form givers to the space, filtering light into the space. Gaps between the building ending and shading surface allowed heated air to escape, and they also were used to define entrances (Fig. 3).

\subsection{Modernists aspiration: the need for speed}

In the 1960s, a sudden oil wealth, an early influx of immigrant workers, in addition to visionary plans from the side of the sheikhdoms, called for major city development. Speed was significantly needed for construction, as fast construction grabbed attention of international media; a goal of the era. Modular construction came in action to fulfil this goal.

Rather than using local materials and labour, a shift towards heavy, pre-fabricated and modular construction started.

Sheikh Rashid Tower design by John R. Harris [6] is an early example of using modular precast facade system influenced by construction methods adopted in Western modernists architecture, but with a more expressive appearance. Islamic figurative representation in this building is quite evident, note the repetitive patterns of geometric motifs in façade treatments providing an interplay of light and shadow (Fig. 4) [7].

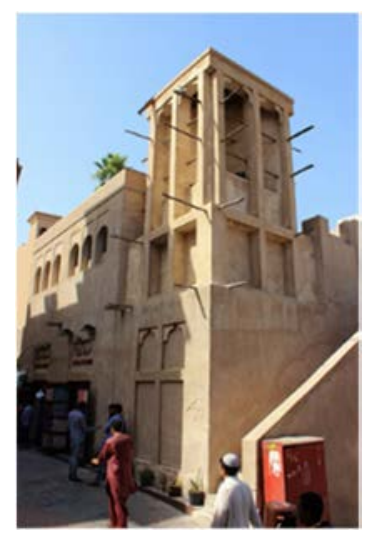

(a)

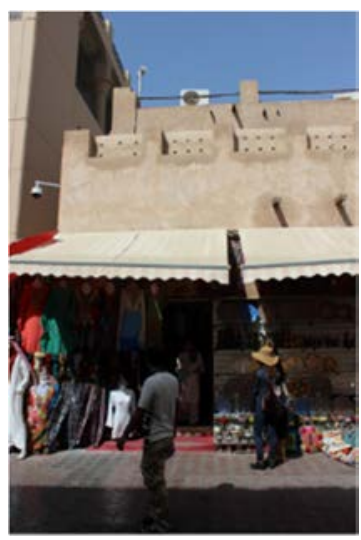

(b)

Figure 2: $\quad$ Examples of traditional environmental regulators at traditional Dubai souks. (a) Wind towers (Barajeel); (b) Air-pullers. 


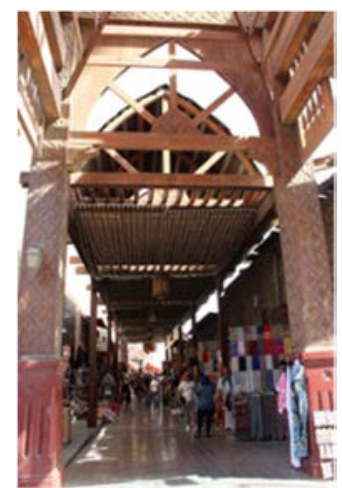

(a)

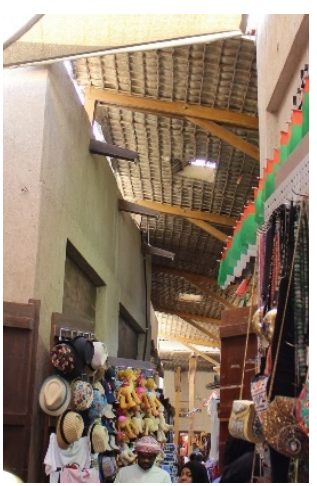

(b)

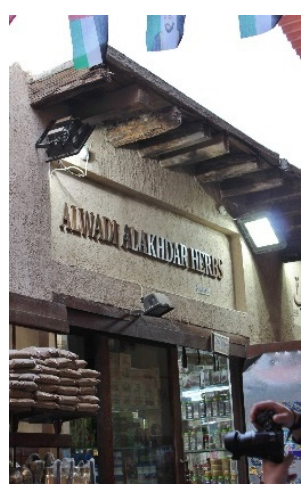

(c)

Figure 3: Examples of different forms and uses of shading devices in old souks. (a) Formgiving; (b) Side ventilation; (c) Defining entrances.

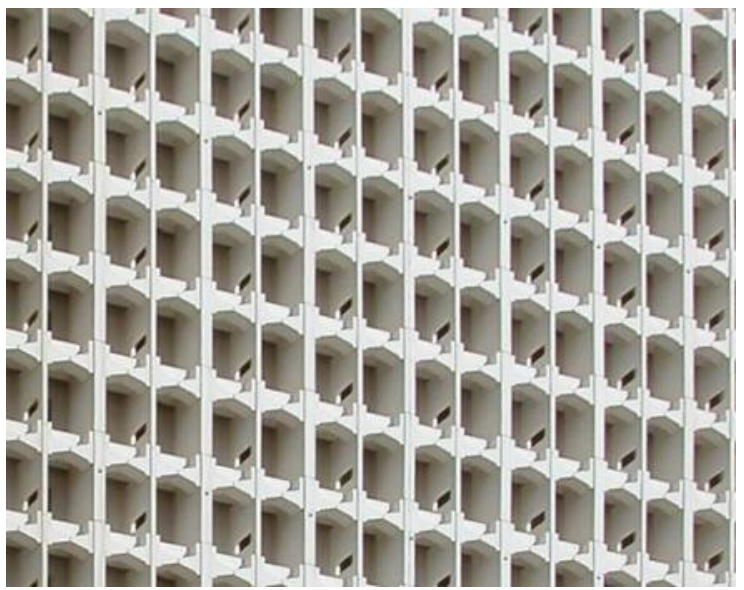

(a)

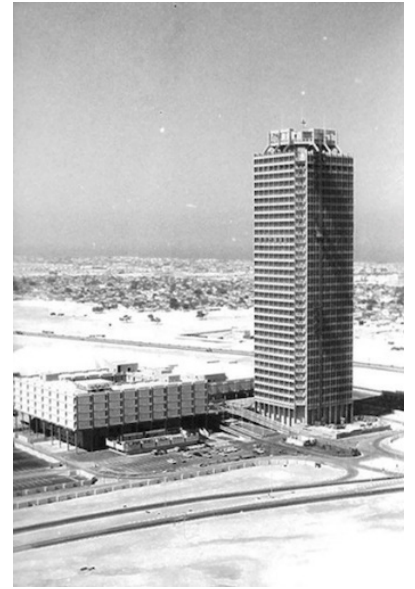

(b)

Figure 4: Sheikh Rashid Tower of the World Trade Center complex, façade detail. Architect John R. Harris and Partners, Dubai, 1979 [7].

The launch of the very first shopping mall, Al Ghurair Center in 1981, diverted the retail environment from the traditional souk to the westernized, large shopping mall. A huge shift from local traditional architecture as known before. Unfortunately, there is lack of information on the construction method which developers have adopted for this building, and the time which the process required. Evidence also diminishes after the recent 2 billion Dirhams expansion which doubled the area of the mall and transformed its spaces [8].

Speed of construction, a need rather than a luxury during this era, dictated the development of alternative methods to achieve this goal. Rather than using local materials and labour, a shift towards heavy, pre-fabricated elements started. This is when developers and construction companies started experimenting in the Dubai construction haven, during 
which, they gained experience in the field, and modular construction in particular gained momentum as well as a larger audience.

\subsection{Hedonistic modernism; the bigger, taller, larger, grander, faster and the spectacular}

By the 1990s, the diversified economy, the growing number of expatriates and tourists, and the creation of lifestyle hubs, resorts and suburbs, contributed to the "Spectacle" of a widely colonized city [3]. During which local architecture seemed to further divert from its origins, and a competition was created among developers seeking the bigger, taller, larger, grander, faster and more spectacular.

Given the high land value, rapid influx of investment, and the rush in completing megaprojects, modular construction found the fertile environment which needed faster and grander architecture. For example, modular air-tight glass curtain walls were used extensively producing well-serviced, dust-free interiors and Manhattan-like exteriors by the end of the 20th century, without taking environmental performance into account [9].

However, Dubai iconic architecture (Fig. 5) [10], [11], still manifested itself as the "contemporary interpretation of Orientalism" [9] and continued to reference Islamic imaginary using superficial figurative motifs and ornamentation inherited from Islamic Art. Modular building elements easily adapted to this imaginary.

As the economic crisis hit in 2008, the market started seeking questions to more essential questions. Cultural, environmental, livable and human-friendly alternatives started grabbing attention from their precedent architecture of spectacle. Low rise developments, offering lifestyle oriented architecture successfully claimed their existence in the city. The qualitative manner in which this architecture is currently evolving did not only seek real answers to real problems, but has just started, I claim, to "architecturally" learn from its past while building for the future. The following section discusses how the previous experiences was able to shape this start.

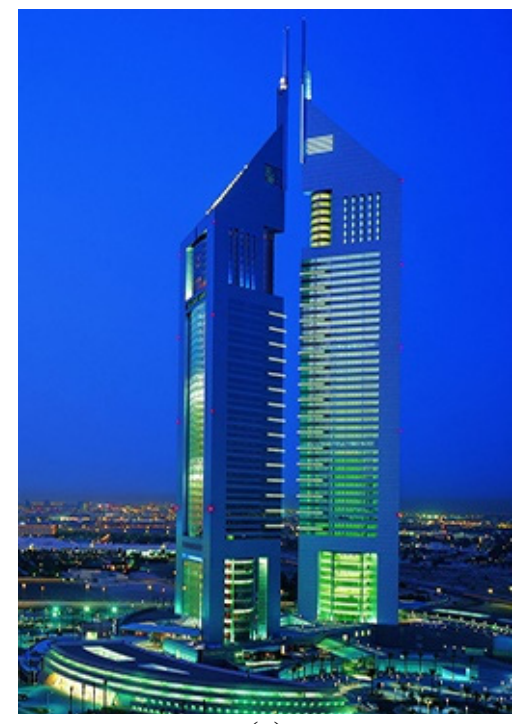

(a)

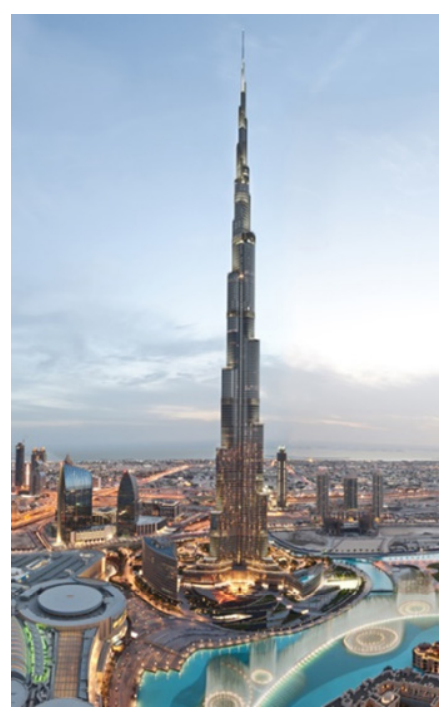

(b)

Figure 5: Examples of Dubai iconic buildings. (a) Emirates Towers, NORR architects; (b) Burj Khalifa, SOM [10], [11]. 


\section{LESSONS FROM THE PAST}

Life-style-oriented retail environments started to emerge during the last decade with updated, much more modest goals. These projects were not exclusively influenced by one of the precedent three eras discussed above, but it is evident that the influence came from a spectrum of architectural experiences throughout the previous decades.

In the following sections, projects developed by the Dubai-based, semi-governmental developer Meraas is taken into account for illustration purposes of such influences. All developments feature walkable, low-rise outdoor environments. The role of modular construction in the transformative nature of these projects cannot be ignored. References to the three periods discussed above is made in order.

\subsection{Origins of local traditional architecture: influences from the pre-modern era}

Reflections of traditional, passive and climate-oriented features was successfully reintroduced. Narrow pedestrian, self-shading walkways, imitations of sikkas connected various retail and entertainment zones aiming at providing shade along the way (Fig. 6).

Gateways defining entrances to souks is an architectural feature that is now featured in over-sized compact volumes with significant projections. The use of modular units produced abstracted volumes, which abandoned ornamentation originally inherited from Islamic arts (Fig. 7).

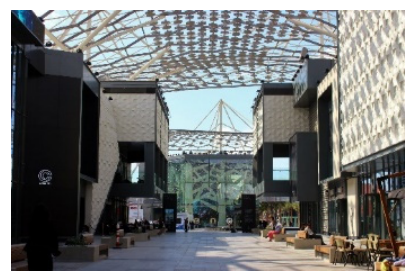

(a)

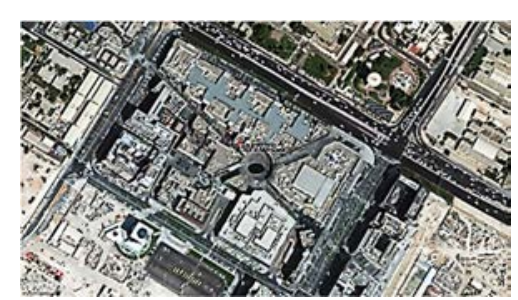

(b)

Figure 6: The dense, shaded walkways re-introduced at City Walk. (a) Shaded walkways; (b) Dense and narrow pedestrian paths.

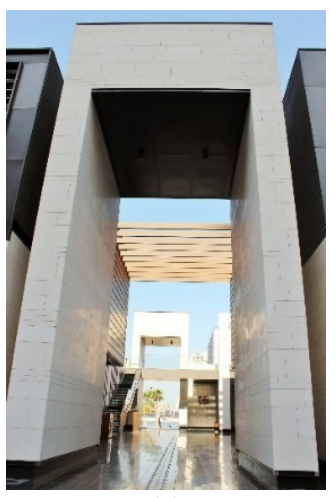

(a)

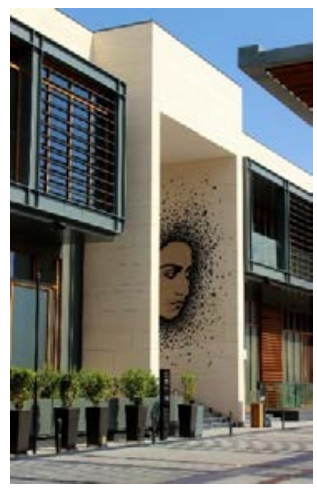

(b)

Figure 7: Over-scaled, modular and abstracted walkways defining souk entrances. (a) The Beach Project; (b) City Walk. 
Environmental regulators of the past, typically wind towers (barajeel) and air pullers are not in use as functional elements. However, their strong figural presence was echoed, probably hosting mechanical systems, or staircases in case of barajeel, and manipulating the cooling effect of the double wall of air pullers through light double-skinned (layered) facades which likewise aim at reducing the heat effect on interior spaces. Shapes forming this second skin has been as well influenced by modular manufacturing.

Also, there is no evidence of using local materials, this is partially due to the use of the industrialized processes shaped with repeating abstracted shapes or units (Fig. 8).

As walkability is a now re-introduced as an essential part of users' experiences, shading is provided by modular manufactured elements replacing local materials with metal or fabric alternatives. Traditional strategies such as shaded entries, and raised shading planes which allow heated air to escape made a come-back. Alternative forms also emerge expressing the flexibility and adaptability which modular construction has to offer (Fig. 9).

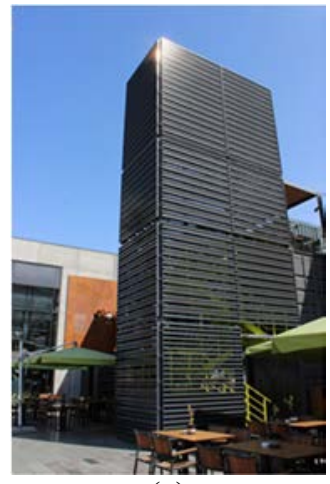

(a)

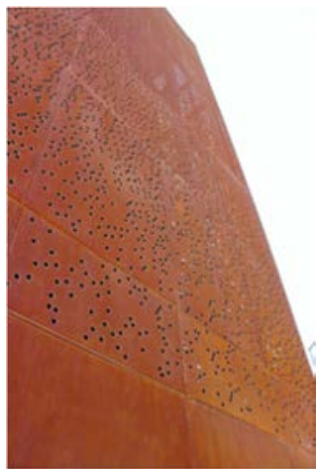

(b)

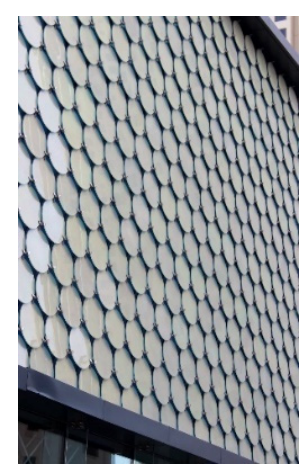

(c)

Figure 8: Examples of architectural features inspired by traditional environmental regulators. (a) Longitudinal inspired by barajeel at BoxPark; (b) Perforated second skin at City Walk; (c) Modular units forming second skin at The Beach.

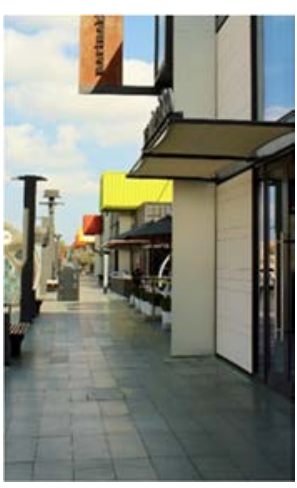

(a)

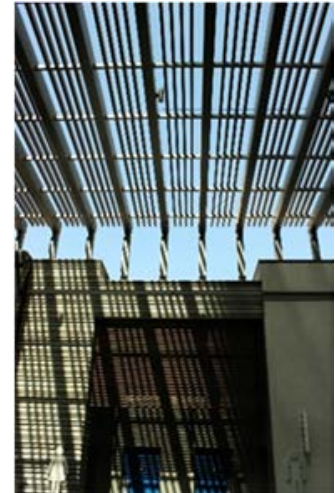

(b)

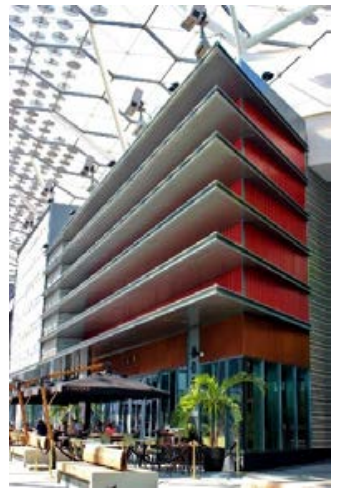

(c)

Figure 9: Examples of uses of modular shading elements. (a) Defining entrances at BoxPark; (b) Side ventilation at the beach; (c) Form giving at City Walk. 


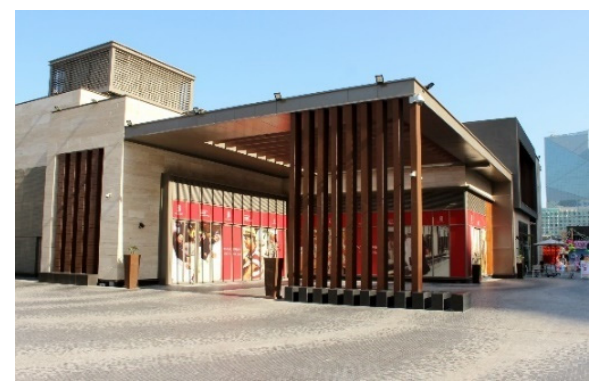

(a)

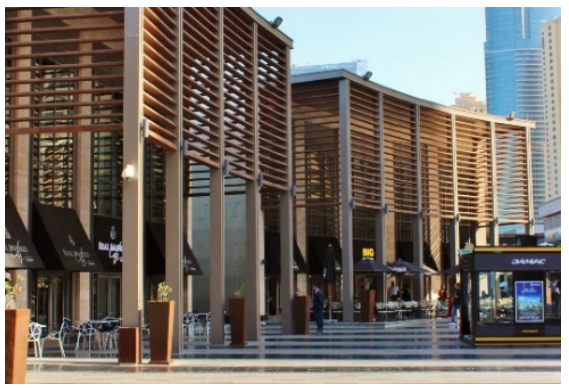

(b)

Figure 10: Modular repetitive and layered elements used as buffer zones at the Beach Project.

3.2 New construction methods featuring cultural references: influences from modernist aspirations

Modular construction still addressed the need for fast construction and was not only evident in the construction method of these projects, but also in the design of alternatives modular units replaced it offering layering, adaptability, depth, pattern, animation, as well as shade replacing traditional ornamentation (Fig. 10).

The small repeatable components are applied on larger contexts allowed explorations of alternative decorative language through modularity and repetitive geometric configurations. This did not only serve the visual side of architecture, but mostly had a performance oriented role in shading and façade layering by acting as a second skin to the building. At a number of occasions, layered skins created buffer zones encouraging the re-introduction of outdoor walkability in retail environments which has long been forgotten (Fig. 10).

References to Islamic patterns and motifs where not necessarily made, however figurative references extended to make cultural, social, political and artistic statements at the local and international levels; like the diverse, cosmopolitan city itself (Fig. 11).

References to Islamic patterns and motifs where not necessarily made, however figurative references extended to make cultural, social, political and artistic statements at the local and international levels; like the diverse, cosmopolitan city itself (Fig. 11).

\subsection{The spectacle reasoned: influences from the Hedonistic modernism}

I do believe that Dubai may not be able to abandon the idea of the "spectacle", leave aside maintaining it as a strategic goal. Still, the young country is aiming to impress and attract global attention. However, Dubai architecture has been able to re-define the meaning of spectacle.

Rather than seeking the bigger, taller, larger, grander, and the faster, spectacle is minimized to much more modest levels, presenting qualitative rather than quantitative qualities. A spectacle which addresses cultural, social, sometimes political statements in relationship to today's reality.

The clean and fully-air conditioned interiors with rich variety of materials for the exteriors was able to achieve this new spectacular, clean look. As volumes tend to reach down to the 


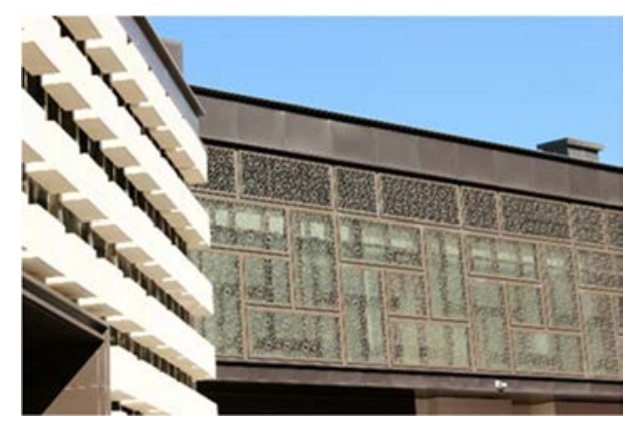

(a)

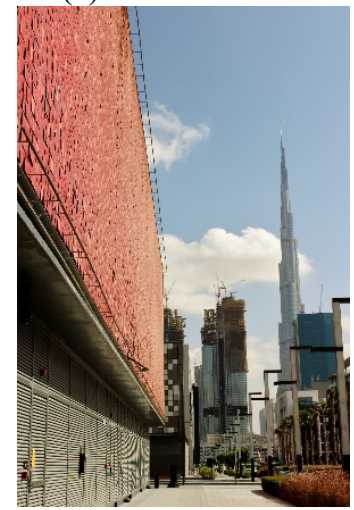

(c)

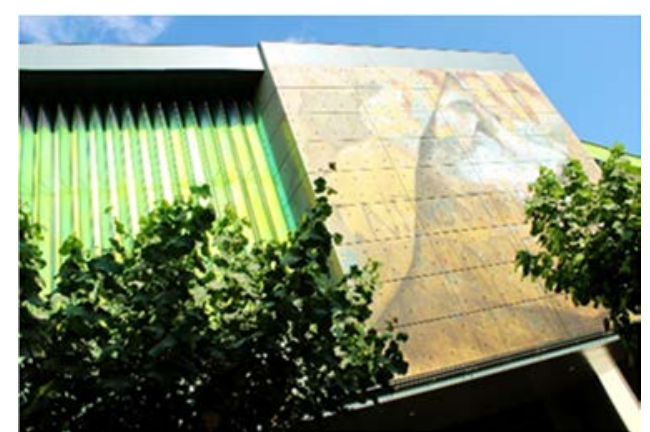

(b)

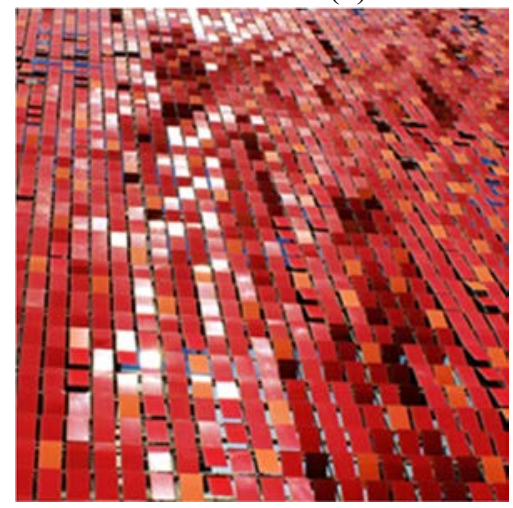

Figure 11: Figurative references made using modular units. (a) Islamic pattern at The Beach; (b) International art work at City Walk; (c) Repetitive and responsive units at City Walk.

human scale, unlike the previous era of glass, Manhattan-like architecture, modular surfaces offer a spectacle of colour, animation and interactivity. The integration of digital technologies, transformed them to LED-operating surfaces which enable projection of performances, incorporating light, sound, and digital production (Fig. 12).

\section{CONCLUSION}

The architecture of Dubai retail environments has been through a number of evolutionary phases. During the last decade, the city witnessed a revival of the old souk concept. However, more than 45 years later, this revival did not only reflect lessons learnt from traditional souks from the pre-oil era but they extended to reflect a long architectural journey which the young city had to witness.

The concept of spectacle which influenced local architecture starting the 1990s was redefined rather than abandoned. Brought down to human scale, the spectacle is re-introduced in the form of rich variation of materials, utilization of digital technologies to transform building surfaces into interactive ones offering social, cultural or even rare political statements, which aim at engaging the society.

Modular construction was able to serve this transformation successfully. As one of the construction methods which gained ground in Dubai due to its relatively low cost, time and 


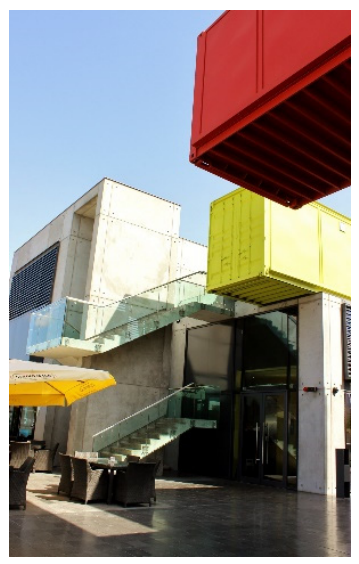

(a)

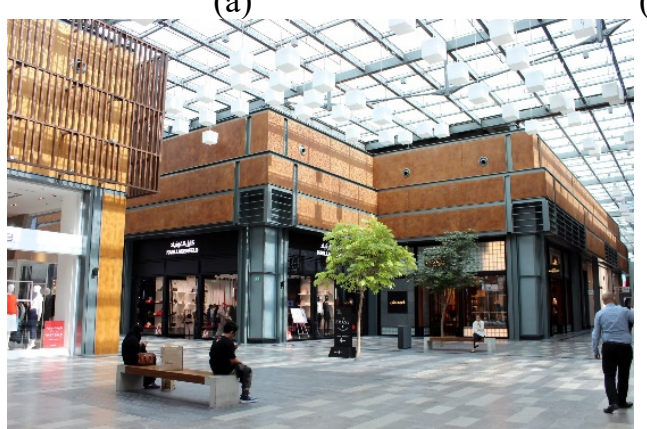

(d)

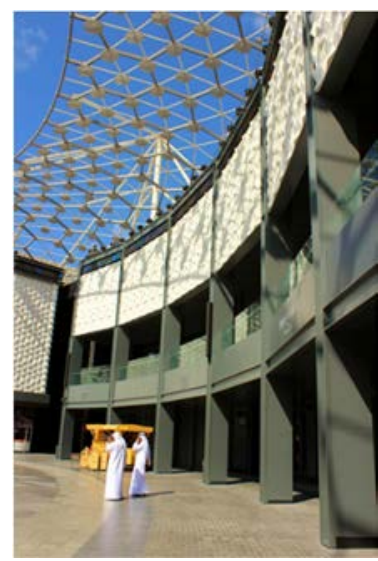

(b)

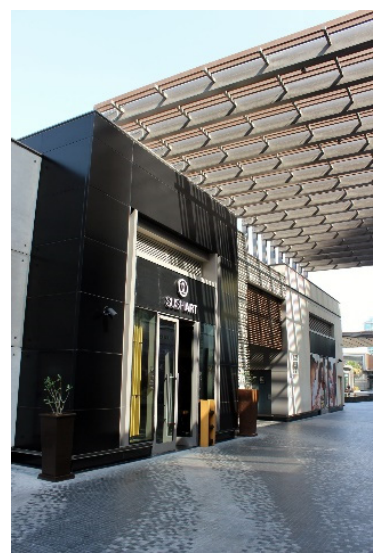

(c)

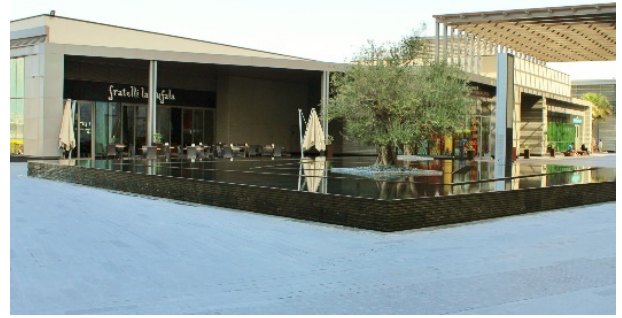

(e)

Figure 12: Modular units offering new visual spectacle. (a) Boldly colored modular containers at Box Park; (b) Interactive LED units shading canopy at City Walk; (c) High variation of high-end finishing at The Beach; (d) Air conditioned "Sikkas" at City Walk (e) Plants and water as natural elements of spectacle at The Beach.

labour. The introduction of new materials, digital and dynamic modelling processes made this transformation possible through the reproduction of smaller modular components. Ornamentation was abandoned to textures, layers, and colours offered by these components.

References to traditional architectural elements are strongly made in a nostalgic, figurative fashion. They abandoned however the passive performance they offered as interior spaces are fully air-conditioned. Also, references to Islamic origins extended to further address regional or international influences.

It is evident that the architecture of Dubai as a city in general and its souks in particular is in constant evolution. Learning from its past experiences, and adapting to local and international variable. I believe that this evolution is not stopping any soon, and there is still more to watch as Dubai, the fastest growing city in the world, offers more to the built environment. 


\section{REFERENCES}

[1] Duncan, G., The evolution of UAE retail: From corner shops to mega malls; The National. Online: www.thenational.ae/business/industry-insights/retail/the-evolutionof-uae-retail-from-corner-shops-to-mega-malls\#full. Accessed on 16 Nov. 2016.

[2] Trujillo, J. \& Parilla, J., The world's 10 fastest growing metropolitan areas; Brookings. Online: $\quad$ www.brookings.edu/blog/the-avenue/2015/02/10/the-worlds-10-fastestgrowing-metropolitan-areas/. Accessed on 3 Jan. 2017.

[3] Elsheshtawy, Y., Navigating the spectacle: Landscapes of consumption in Dubai. Architectural Theory Review, 13(2), pp. 164-187, 2008.

[4] Velegrinis, S. \& Katodrytis, G., Drawing on Sand: Cities in the making. Architectural Design, 85(1), pp. 72-79, 2015.

[5] Dubai Municipality, General Projects Department, Historical Buildings Section. Elements of Traditional Architecture in Dubai, 4th ed., Dubai, 2006.

[6] Boake, T., The Evolution of Tall Building in the Gulf: From the Sensational to the Sensitive. Architectural Design, 85(1), pp. 54-71, 2015.

[7] Mezaina, H., Lest We Forget: Structures of Memory in the United Arab Emirates at the 14th International Architecture Biennale. Online: www.theculturist.com/ home/tag/sheikh-rashid-tower-of-the-world-trade. Accessed on 28 March 2017.

[8] Scott, A., Malls of the UAE, part 2: Al Ghurair Centre a gem at the heart of old Dubai; The National. Online: www.thenational.ae/business/retail/malls-of-the-uae-part-2-alghurair-centre-a-gem-at-the-heart-of-old-dubai. Accessed on 5 March 2017.

[9] Katodrytis, G., Performative Urbanism, an Emerging Model of the Gulf. Architectural Design, 85(1), pp. 121-127, 2015.

[10] Visit Dubai. Online: www.visitdubai.com/en. Accessed on 26 March 2017.

[11] Burj Khalifa. Online: www.burjkhalifa.ae/en/index.aspx. Accessed on 26 March 2017. 